\title{
Determining the growth and mortality parameters of longtail tuna (Thunnus tonggol Bleeker, 1851) using length frequency data in coastal waters of the northern Persian Gulf and Oman Sea, Iran
}

\author{
Mehran Yasemi • Alireza Nazari Bajgan · Mehran Parsa
}

Received: 28 November 2016/Accepted: 17 July 2017/Published online: 22 July 2017

(C) The Author(s) 2017. This article is an open access publication

\begin{abstract}
Longtail tuna (Thunnus tonggol) is one of the most economically important tuna species in Iranian waters of Persian Gulf and Oman Sea. Some population dynamics parameters of this species were investigated in coastal waters of the northern Persian Gulf and Oman Sea from January to December 2014. The fork length (FL) of all specimens ranged from 27 to $107 \mathrm{~cm}$, and total weight (TW) was between 200 and 12,000 g. Among the length frequencies examined, specimens with fork length in the range of $62-65 \mathrm{~cm}$ were the dominant group. The equation of length-weight relationship was estimated as TW $=0.00003 \times \mathrm{FL}^{2.82}$ $\left(R^{2}=0.84\right)$ and isometric growth model was determined for longtail tuna in study area. The parameters of Von Bertalanffy growth function were obtained as: $L_{\infty}=111.23 \mathrm{~cm}, k=0.3$ year $^{-1}$ and $t_{0}=-0.38$ years and $\phi^{\prime}=3.6$. The annual instantaneous rate of total mortality $(Z)$, natural mortality $(M)$ and fishing mortality $(F)$ was estimated to be $1.15,0.43$ and 0.72 year $^{-1}$, respectively. The exploitation rate $(E)$ was calculated as 0.63 indicating that longtail tuna was fully exploited in the study region.
\end{abstract}

Keywords Growth $\cdot$ Mortality $\cdot$ Longtail tuna $\cdot$ Persian Gulf $\cdot$ Oman Sea

\section{Introduction}

Tuna fishes, Scombridae family, are one of the most economically important marine resources for industrial fishing activities in the Persian Gulf and Oman Sea (Kamrani et al. 2010). The Scombridae is a family of 15 genera and about 50 species of epipelagic marine fishes (Block and Stevens 2001). The main tuna species caught in the Iranian waters of Persian Gulf and Oman Sea are: longtail tuna (Thunnus tonggol Bleeker, 1851), yellowfin tuna (Thunnus albacares Bonnaterre, 1788), skipjack tuna (Katsuwonus pelamis Linnaeus, 1758), kawakawa (Euthynnus affinis Cantor, 1849), frigate tuna (Auxis thazard Lacepede, 1800), Narrow-barred Spanish mackerel (Scomberomorus commerson Lacepede, 1800) and Indo-Pacific king mackerel (Scomberomorus guttatus Bloch \& Schneider, 1801). Tuna fishes constitute around 50\% of total landings of

M. Yasemi ( $\square)$

Institute of Applied-Scientific Higher Education of Jahad-e-Agriculture, Agricultural Research, Education and Extension

Organization, Tehran, Iran

e-mail: yasemi_m@yahoo.com

A. N. Bajgan

Higher Education Center of Jahad-e-Agriculture Hormozgan, Bandar Abbas, Iran

M. Parsa

Young Researchers and Elite Club, Bandar Abbas Branch, Islamic Azad University, Bandar Abbas, Iran 
the Hormozgan province and total annual commercial landings of tuna fishes in Iranian waters of Persian Gulf and Oman Sea were around 175,000 tonnes. Longtail tuna represented 46\% of total catch (Iran Fishery Organization 2013).

Longtail tuna is an epipelagic species inhabiting tropical to temperate regions of the Indo-Pacific, found almost exclusively in the neritic waters close to the shore, avoiding estuaries, turbid wasters and open Ocean. This species primarily caught by gillnet fleets operating in coastal waters with the highest reported catches from Iran, Indonesia, Pakistan, Malaysia and, to Oman, Yemen, India and Thailand (Pierre et al. 2014).

Knowledge of growth and mortality parameters is essential for understanding the population dynamics of different species. Several approaches were often used to determine the age and growth of the aquatic species, such as length-frequency analyses, tagging and recapture experiments and observations of the mark on the hard parts (scales, otoliths, spines and vertebrates) (Stequert et al. 1996). Particular morphometric measurements, such as length-weight relationship (LWR), are useful in fishery management and stock assessment models (Barría et al. 2014), and has been widely used in the environmental monitoring programs such as calculation of fish weight at a certain length and the conversion of an equation of growth in weight and vice versa, as well as the calculation of a condition index to allow for morphological comparisons of populations among different regions (Yoon et al. 2013; Oliveira et al. 2014). The general biology and population dynamics of the several tuna species have been researched in Iranian waters of Persian Gulf and Oman Sea (Kaymaram et al. 2010; Taghavi Motlagh et al. 2010; Hosseini and Ehsani 2014). Nevertheless, scanty information is available on growth and mortality characteristics of longtail tuna in this region http://www.jifro.ir/files/site1/ user_files_eb12be/admin-A-10-1-11-532319e.pdf. Therefore, the specific objectives of present study were to determine: (1) the length and weight frequency structure (length-weight relationship), (2) the growth parameters $\left(L_{\infty}, K, T_{0}\right)$ using the length-based MULTIFAN method (3) the mortality parameters based on the length-converted catch curve and Pauly's empirical equation, and (4) the exploitation rate of the longtail tuna in coastal waters of the northern Persian Gulf and Oman Sea, Iran.

\section{Materials and methods}

Study area and sampling

Using commercial gill nets, specimens of longtail tuna were collected monthly and randomly in coastal waters of the northern Persian Gulf and Oman Sea (Hormozgan province, Iran) from January to December 2014 (Fig. 1). Sampling was carried out from five different landing sites including Bandar lengeh $\left(54^{\circ} 22^{\prime} \mathrm{E}\right.$ and $\left.26^{\circ} 39^{\prime} \mathrm{N}\right)$, Gheshm Island $\left(55^{\circ} 41^{\prime} \mathrm{E}\right.$ and $\left.26^{\circ} 41^{\prime} \mathrm{N}\right)$, Bandar Abbas $\left(56^{\circ} 15^{\prime} \mathrm{E} 27^{\circ} 11^{\prime} \mathrm{N}\right)$, Sirik $\left(57^{\circ} 05^{\prime} \mathrm{E}\right.$ and $\left.26^{\circ} 20^{\prime} \mathrm{N}\right)$ and Jask $\left(57^{\circ} 47^{\prime} \mathrm{E}\right.$ and $\left.25^{\circ} 39^{\prime} \mathrm{N}\right)$. A total of 2163 individuals were examined during the study period.

Length-weight relationship

The length frequency distribution of longtail tuna caught in different months was determined. For each specimen, the fork length (FL) was measured with a measuring board to the nearest $1 \mathrm{~cm}$, and total body weight (TW) was measured on a digital scale to $1 \mathrm{~g}$. The relationship between length and weight was calculated using the following equation (Ricker 1975):

$$
\mathrm{TW}=a \mathrm{FL}^{b}
$$

where TW is the total weight $(\mathrm{g}), \mathrm{FL}$ is the fork length $(\mathrm{cm}), a$ is the intercept of the regression and $b$ is the regression coefficient indicating isometric growth when equal to 3 . The best regression parameters were obtained by minimizing the residuals errors by the least square residuals method (Haddon 2011).

Student's $t$ test was utilized to confirm whether the declivity of regression (constant " $b$ ") presented a significant difference with 3 , indicating the type of growth: isometric $(b=3)$, positive allometric $(b>3)$ or negative allometric $(b<3)$ (Sokal and Rohlf 1987). 


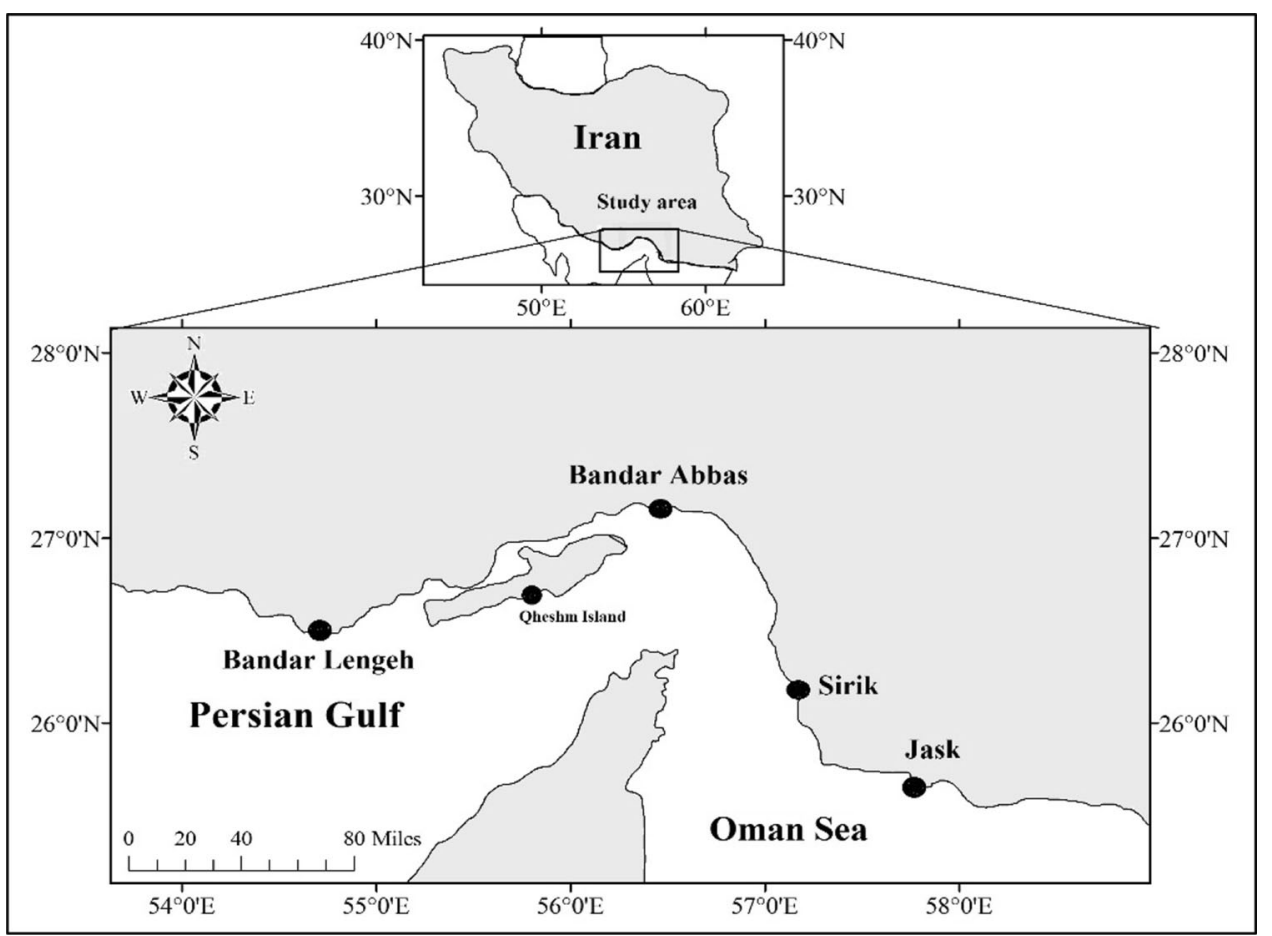

Fig. 1 Map of study area and location of sampling ports for longtail tuna (northern Persian Gulf and Oman Sea, Iran)

$$
t_{\mathrm{s}}=\frac{b-3}{s b}
$$

where $t_{\mathrm{s}}$ is the $t$ test value, $b$ is the slope and $s b$ is the standard error of the slope $(b)$.

Growth parameters

Length frequency data were used to calculate the von Bertalanffy growth rate $(k)$ and the asymptotic length $\left(L_{\infty}\right)$ by model progression analysis using the FiSAT program (Gayanilo et al. 1996) and ELEFAN I method (Pauly 1984). The best value of growth parameter $(k)$ for the given value of $L_{\infty}$ was identified by Shepherd's method and scan of $k$ values option from Assess menu. A classical von Bertalanffy growth function (VBGF) was fitted to the data using the following formula (Sparre and Venema 1998):

$$
L_{\mathrm{t}}=L_{\infty}\left(1-\exp \left(-k\left(t-t_{0}\right)\right)\right)
$$

In this equation, $t_{0}$ represents the theoretical age at length zero, $L_{\infty}$ is the asymptotic length and $L_{\mathrm{t}}$ is the length at age. Estimation of the $t_{0}$ parameter was determined by empirical equation proposed by Pauly (1983):

$$
\log 10\left(-t_{0}\right)=-0.392-0.275 \log 10 L_{\infty}-1.038 k
$$

Mortality parameters

The length-converted catch curve was applied for the calculation of the instantaneous annual mortality rate $(Z)$ (Pauly 1983). The growth performance index $\left(\phi^{\prime}\right)$ was calculated using the following formulae (Pauly and Munro 1984):

$$
\phi^{\prime}=\log K+2 \log L_{\infty}
$$


The natural mortality $(M)$ was calculated by Pauly’s empirical equation:

$$
\log M=0.1228-0.192 \log L_{\infty}+0.7485 \log K+0.2391 \log T,
$$

where $T$ is the mean annual temperature (in ${ }^{\circ} \mathrm{C}$ ), which is assumed to reflect the locally sea surface temperature in the survey area (Pauly 1984) (in the present study, $T=27^{\circ} \mathrm{C}$ ).

For the calculation of the fishery mortality $(F)$, the $M$ value was subtracted from the $Z$ value to get the fishing mortality (Appeldoom 1984).

$$
F=Z-M
$$

With the estimated values of $F$ and $Z$, the rate of exploitation $(U)$ was calculated using the following formulae (Gulland 1985):

$$
E=\frac{F}{Z}
$$

\section{Results}

The annual length frequency of longtail tuna is shown in Fig. 2. A total of 2163 specimens sampled in five landing sites. The fork length of longtail tuna was in the range of $27-107 \mathrm{~cm}$. Along the length range analyzed, the highest length frequency obtained was in the range of $62-65 \mathrm{~cm}$. The average length obtained was between 59 and $63 \mathrm{~cm}$ with no difference between months.

Figure 3 represents the length-weight relationships of longtail tuna during a 1 year period and in different seasons. The length-weight relationship during a 1 year period was estimated to be TW $=0.00003 \times \mathrm{FL}^{2.82}$ $\left(R^{2}=0.84\right)$. The $b$ value of relationship between length and weight was ranged from 2.70 (summer) to 2.89 (spring). According to the obtained $b$ value and using the Student's $t$ test, isometric growth model was determined for longtail tuna in the study area $(P>0.05)$.

The von Bertalanffy growth curves of longtail tuna are shown in Fig. 4. The growth parameters estimated by ELEFAN I were as: $L_{\infty}=111.23 \mathrm{~cm}$ fork length, $t_{0}=-0.38$ year, $\phi^{\prime}=3.6$. The $k$ value was 0.3 year $^{-1}$ (Fig. 5). The estimated age in different fork length classes is represented in Table 1.

The length-converted catch curve of longtail tuna is shown in Fig. 6. The estimated rates of total mortality $(Z)$ and natural mortality rate $(M)$ were 1.15 and 0.43 year $^{-1}$, respectively. The fishing mortality $(F)$ was 0.72 year $^{-1}$. The exploitation rate $(E)$ for population of longtail tuna was calculated as $E=0.63$.

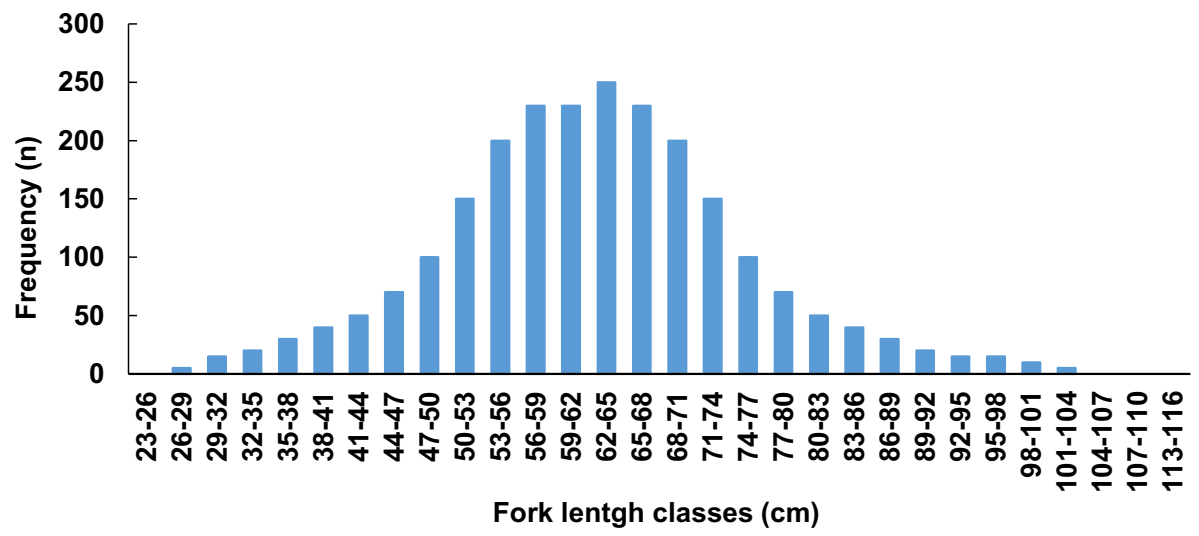

Fig. 2 Annual fork length frequency distribution of longtail tuna in northern Persian Gulf and Oman Sea, Iran 



Fig. 3 Length-weight relationships of longtail tuna during a 1 year period and different seasons in northern Persian Gulf and Oman Sea, Iran

\section{Discussion}

The length-frequency-based analysis is used widespread at the present time, especially in the tropical and subtropical regions (Sparre and Venema 1998). This method becomes important when other aging techniques are either not possible or very expensive (Wang and Ellis 2005). According to Zhu et al. (2011), the study of growth using length-frequency analysis has long been the most frequently used method.

Gulland and Rosenberg (1992) noted that sampling from large number of smaller samples than sampling from a limited number of larger samples will always give more information, while providing estimates with smaller variance. In this regard, two samples of 150 fish will always give more information than one of 300 fish, but will take more time. Furthermore, a sample of 50-150 fish/month and an annual sample of 1000-1500 fish provide the most reliable image on the biological characteristics of a specific species. To have most 




Fig. 4 The von Bertalanffy growth curves of longtail tuna in northern Persian Gulf and Oman Sea, Iran

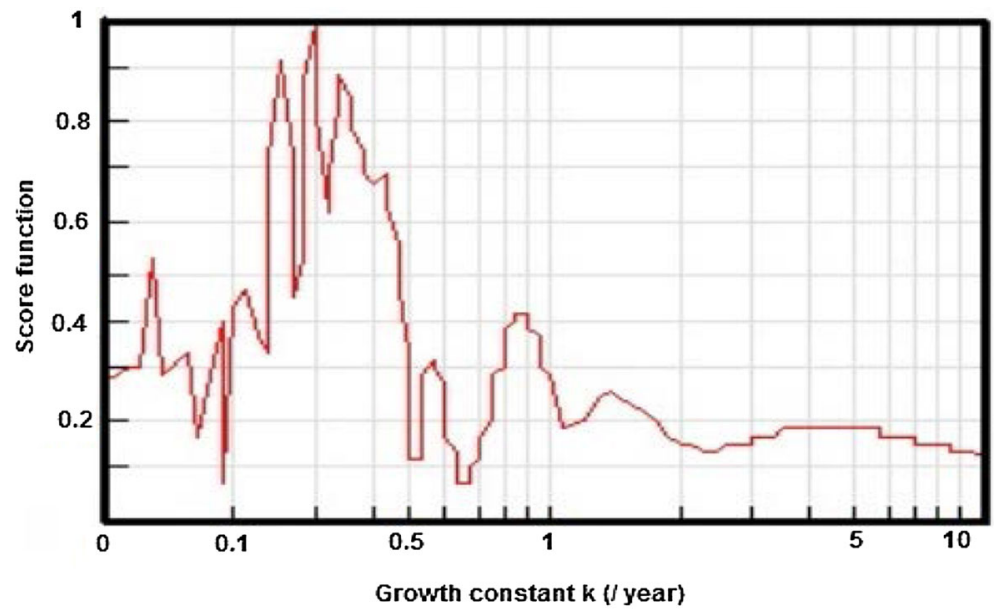

Fig. 5 Shepherd's method with maximum score $\left(S_{\max }\right)$ appropriate to the best value of growth coefficient of longtail tuna in northern Persian Gulf and Oman Sea, Iran

reliable understanding on the biology of longtail tuna distributed in coastal waters of the northern Persian Gulf and Oman Sea, sampling was done in five different landing sites and covered 12 months (180 fish/month).

According to IGFA (2001), the maximum fork length of longtail tuna was found to be $147 \mathrm{~cm}$. The length frequency of long tail tuna captured from the traditional fishing was 26-130 cm (Darvishi et al. 2003). The author found significant differences in the length frequency of long tail tuna between the traditional and commercial fishing which might probably be governed by the sampling methods and fishing tools. Fish with mean length of $30 \mathrm{~cm}$ have been reported in the gillnet catches of long tail tuna in Oman Sea waters in October while the average size was found to be 36 and $46 \mathrm{~cm}$ for February and May, respectively.

Abdussamad et al. (2012) have reported that longtail tuna along the Indian Coast is supported by fishery having a length range of $23-111 \mathrm{~cm}$ and a mean length of $60.5 \mathrm{~cm}$ in gillnets fishery. Khorshidian and Carrara (1993) indicated the differences in size composition of longtail tuna between the Iranian and Omani fisheries on the northern and southern shores of the Oman Sea. Size-related migration or differences in the mesh size of the gill nets used were possibly contributed to this difference. No differences in the monthly length frequency of longtail tuna were observed. Moreover, the average length was lower than that at first sexual maturity, indicating overfishing or the use of small mesh size nets.

Among the biometric relations in fishes, the length-weight relationships are greatly presented by scientists and researchers as useful tools in fish biology (King 2007; Ferreira et al. 2008). Calculation of the lengthweight relationship parameter is useful for the prediction of weight from length values, condition of fish, stock assessment, and estimation of biomass (Valset et al. 2007). 
Table 1 Detailed data on relationship between fork length classes and estimated age for longtail tuna in northern Persian Gulf and Oman Sea, Iran

\begin{tabular}{|c|c|c|c|c|c|c|c|c|c|c|}
\hline \multirow{2}{*}{$\begin{array}{l}\text { Length group } \\
\text { (cm) }\end{array}$} & \multicolumn{9}{|c|}{ Age (year) } & \multirow[t]{2}{*}{ Numbers } \\
\hline & 1 & 2 & 3 & 4 & 5 & 6 & 7 & 8 & 9 & \\
\hline $26-29$ & 1 & - & - & - & - & - & - & - & - & 1 \\
\hline $29-32$ & 5 & - & - & - & - & - & - & - & - & 5 \\
\hline $32-35$ & 4 & - & - & - & - & - & - & - & - & 4 \\
\hline $35-38$ & 21 & - & - & - & - & - & - & - & - & 21 \\
\hline $38-41$ & 29 & - & - & - & - & - & - & - & - & 29 \\
\hline $41-44$ & 46 & - & - & - & - & - & - & - & - & 46 \\
\hline $44-47$ & 69 & - & - & - & - & - & - & - & - & 69 \\
\hline $47-50$ & 68 & - & - & - & - & - & - & - & - & 68 \\
\hline $50-53$ & 143 & - & - & - & - & - & - & - & - & 143 \\
\hline $53-56$ & 226 & - & - & - & - & - & - & - & - & 226 \\
\hline $56-59$ & 66 & 116 & - & - & - & - & - & - & - & 182 \\
\hline $59-62$ & - & 268 & - & - & - & - & - & - & - & 268 \\
\hline $62-65$ & - & 227 & - & - & - & - & - & - & - & 227 \\
\hline $65-68$ & - & 217 & - & - & - & - & - & - & - & 217 \\
\hline $68-71$ & - & 227 & - & - & - & - & - & - & - & 227 \\
\hline $71-74$ & - & - & 128 & - & - & - & - & - & - & 128 \\
\hline $74-77$ & - & - & 96 & - & - & - & - & - & - & 96 \\
\hline $77-80$ & - & - & 43 & - & - & - & - & - & - & 43 \\
\hline $80-83$ & - & - & 28 & 8 & - & - & - & - & - & 36 \\
\hline $83-86$ & - & - & - & 53 & - & - & - & - & - & 53 \\
\hline $86-89$ & - & - & - & 26 & - & - & - & - & - & 26 \\
\hline 89-92 & - & - & - & - & 5 & - & - & - & - & 5 \\
\hline $92-95$ & - & - & - & - & 16 & - & - & - & - & 16 \\
\hline $95-98$ & - & - & - & - & - & 13 & - & - & - & 13 \\
\hline 98-101 & - & - & - & - & - & 2 & 6 & - & - & 8 \\
\hline 101-104 & - & - & - & - & - & - & 2 & 3 & - & 5 \\
\hline 104-107 & - & - & - & - & - & - & - & - & 1 & 1 \\
\hline Total & 678 & 1055 & 295 & 87 & 21 & 15 & 8 & 3 & 1 & 2163 \\
\hline
\end{tabular}



Fig. 6 Length-converted catch curve for longtail tuna in northern Persian Gulf and Oman Sea, Iran 
In our study, the length-weight relationship was estimated to be $W=0.00003 \times \mathrm{FL}^{2.82}\left(R^{2}=0.84\right)$. To verify if $b$ was significantly different from the isometric value $(b=3)$, the Student's $t$ test $\left(H_{0}: b=3\right)$ was utilized. Results showed no difference between obtained $b$ value (2.82) and 3 and isometric growth model was determined for longtail tuna in study area $(P>0.05)$. Biswass $(1993)$ and Froese (2006) presented the acceptable range of $b$ value between 2.5 and 3.5 that is in agreement with our estimation. Length-weight relationship for longtail tuna was estimated as $W=0.0148 \times L^{3.0}$ in waters of India (Abdussamad et al. 2012), indicating a perfect isometric pattern in growth that is in agreement with the results of our study. Griffiths et al. (2010) estimated the length-weight relationship of longtail tuna as $W=0.00005 \times L^{2.82}$ in tropical and temperate waters of the central Indo-Pacific that is completely in agreement with our findings.

The growth parameters of longtail tuna estimated by ELEFANI were as: $L_{\infty}=111.23 \mathrm{~cm}$ fork length, $t_{0}=-0.38$ year, $\phi^{\prime}=3.6$. The $k$ value was 0.3 year $^{-1}$. Studies in different regions have indicated that the $L_{\infty}$ of longtail tuna was differed from $55 \mathrm{~cm}$ in waters of Japan (Itoh et al. 1999) to $135.4 \mathrm{~cm}$ in Australia (Griffiths et al. 2010) and the range for $k$ was 0.228 in Oman (Prabhakar and Dudley 1989) to 1.7 in waters of Japan (Itoh et al. 1999). The $L_{\infty}$ estimated in our study for the longtail tuna was higher than the estimates given by some previous studies (Supongpan and Saikliang 1987; Yesaki 1989; Itoh et al. 1999) but lower than that by Griffiths et al. (2010) and Abdussamad et al. 2012.

Difference in the growth parameters estimated by other authors may be due to the fact that the data used for different analytical methods by them were obtained by different gears such as drift gillnets, hooks and lines, troll and trawls (Pillai et al. 2002). Taghavi Motlagh et al. (2010) declared that different values of $L_{\infty}$ and $k$ might be associated with sampling error, variation in fishing intensity or environmental conditions. Moreover, slight differences in growth patterns can be the results of differences in genetic structure, differences in temperature, density of food and diseases (Wootton 1998). Age at zero length $\left(-t_{0}\right)$ was calculated to be -0.38 year and, according to King (2007), it means juveniles of longtail tuna grow more quickly than adults.

The total mortality for longtail tuna was 1.15 year $^{-1}$. Abdussamad et al. 2012 presented a total mortality rate as 3.85 year $^{-1}$ for longtail tuna in Indian waters that was considerably higher than our results. The instantaneous natural mortality coefficient $(M)$ was $0.43 \mathrm{year}^{-1}$ in the present study. Our result was lower than the instantaneous natural mortality coefficient estimated for the same species in the Indian waters, 0.77 year $^{-1}$ (Abdussamad et al. 2012) and 0.8 year $^{-1}$ (James et al. 1993). SU et al. (2003) declared that the estimation of natural mortality poses some difficulty because it may be affected by the selection of the estimation method and the study area.

The exploitation rate for population of longtail tuna $(E=0.63)$ in the present study was high. Gulland (1985) stated that in an optimally exploited stock, fishing mortality should be equal to natural mortality, resulting in an exploitation rate of 0.5 . Patterson (1992) declared that the fishing rate satisfying optimal $E$ level of 0.5 tended to reduce pelagic fish stock abundance and, hence, the former author suggested that $E$ should be maintained at 0.4 for optimal exploitation of those stocks. The present estimate of $E$ suggests that the population of longtail tuna in the waters of northern Persian Gulf and Oman Sea is being heavily exploited and overfished at a higher level than the optimum and a better management policy is necessary in this area. The decision making on fisheries management of longtail tuna cannot use only biological information; thus, the socioeconomic condition of small-scale fishermen in waters of the Persian Gulf and Oman Sea should be considered to achieve sustainable management of longtail tuna resources. Finally, results of this study are particularly helpful for drift gillnet fisheries management in the Persian Gulf and Sea of Oman.

Open Access This article is distributed under the terms of the Creative Commons Attribution 4.0 International License (http:// creativecommons.org/licenses/by/4.0/), which permits unrestricted use, distribution, and reproduction in any medium, provided you give appropriate credit to the original author(s) and the source, provide a link to the Creative Commons license, and indicate if changes were made.

\section{References}

Abdussamad EM, Said Koya KP, Ghosh S, Rohit P, Joshi KK, Manojkumar B, Prakasan D, Kemparaju S, Elayath MNK, Dhokia HK, Sebastine M, Bineesh KK (2012) Fishery, biology and population characteristics of longtail tuna, Thunnus tonggol (Bleeker, 1851) caught along the Indian coast. Indian J Fish 59(2):7-16

Appeldoom RS (1984) The effect of size on mortality of small juvenile conchs (Strombus gigas L. and S. costatus G.). J Shellfish Res 4:37-43 
Barría C, Navarro J, Coll M, Fernandez-Arcaya U, Sáez-Liante RS (2014) Morphological parameters of abundant and threatened chondrichthyans of the northwestern Mediterranean Sea. J Appl Ichthyol 31(1):114-119

Biswas SP (1993) Manual of methods in fish biology. South Asian, New Delhi

Block BA, Stevens ED (2001) Tuna (physiology, ecology and evolution). Academic Press, Massachusetts

Darvishi M, Kaymaram F, Talebzadeh SA, Behzadi S (2003) Population dynamics of five Scombrid fish in Hormuzgan Province (Iran). Persian Gulf and Oman Sea. Ecological Research Institute, Iran (In Persian)

Ferreira S, Sousa R, Delgado J, Carvalho D, Chada T (2008) Weight-length relationships for demersal fish species caught off the Madeira archipelago (eastern-central Atlantic). J Appl Ichthyol 24(1):93-95

Froese R (2006) Cube law, condition factor and weight-length relationships: history, meta-analysis and recommendations. J Appl Ichthyol 22(4):241-253

Gayanilo FC, Parre PS, Pauly D (1996) The FAO ICLARM stock assessment tools (FISAT). User's guide. FAO Computerized Information Series Fisheries, Rome

Griffiths SP, Fry GC, Manson FJ, Lou DC (2010) Age and growth of longtail tuna (Thunnus tonggol) in tropical and temperate waters of the central Indo-Pacific. ICES J Mar Sci 67:125-134

Gulland JA (1985) Fish stock assessment: a manual of basic methods. Wiley, New York

Gulland JA, Rosenberg AA (1992) A review of length-based approaches to assessing fish stock. FAO Fisheries Technical Paper, Rome

Haddon M (2011) Modelling and quantitative methods in fisheries. Chapman and Hall Press, Florida

Hosseini SA, Ehsani E (2014) An investigation of reactive behavior of yellowfin tuna schools to the purse seining process. Iran J Fish Sci 13:330-340

IGFA (2001) Database of IGFA angling records until 2001. IGFA, Fort Laudedale

Iran Fishery Organization (2013) Fisheries data statistics of 2012. Iran Fishery Organization (IFO) Press, Tehran

Itoh T, Yuki Y, Tsuji S (1999) Spawning possibility and growth of longtail tuna, Thunnus tonggol, in the water around Japan. Bull Natl Res Inst Far Seas Fish 36:47-53

James PSBR, Pillai PP, Pillai NGK, Jayaprakash AA, Gopakumar G, Kasim HM, Sivadas M, Koya KPS (1993) Fishery, biology and stock assessment of small tunas. In: Sudarsan D, John ME (eds) Tuna research in India. Fishery survey of India, Bombay, pp 123-148

Kamrani E, Sabili AN, Yahyavi M (2010) Stock assessment and reproductive biology of the blue swimming crab, Portunus pelagicus in Bandar Abbas Coastal Waters, Northern Persian Gulf. Iran J Persian Gulf 11:11-22

Kaymaram F, Hossainy SA, Darvishi M, Talebzadeh SA, Sadeghi MS (2010) Reproduction and spawning patterns of the Scomberomorus commerson in the Iranian coastal waters of the Persian Gulf and Oman Sea. Iran J Fish Sci 9:233-244

Khorshidian K, Carrara G (1993) An analysis of length frequencies of Thunnus tonggol in Hormozgan waters. In: Ardill JD (ed) Proceedings of the expert consultation on Indian Ocean Tunas, 5th Session, Mahe, Seychelles

King M (2007) Fisheries biology, assessment and management. Wiley-Blackwell Publishing, New Jersey

Oliveira VA, Loverde-Oliveir SM, Mateus LA, Teixeira-de Mello F (2014) Length-weight relationships of 26 fish species from the streams of the upper section of the Paraguay River basin (Mato Grosso, Brazil). J Appl Ichthyol 31:225-227

Patterson K (1992) Fisheries for small pelagic species: an empirical approach to management targets. Rev Fish Biol Fish 2(4):321-338

Pauly D (1983) Some simple methods for the assessment of tropical fish stocks. Fisheries Technical Paper, Rome

Pauly D (1984) Fish population dynamics in tropical waters: a manual for use with programmable calculators. International Center for Living Aquatic Resources Management, Philippines

Pauly D, Munro JL (1984) Once more on the comparisons of growth in fish and invertebrates. ICLARM Fishbyte 2(1):21

Pierre L, Geehan J, Herrera M (2014) Review of the statistical data available for bycatch species. IOTC, pp 17-19

Pillai NGK, Menon NG, Pillai PP, Ganga U (2002) Management of Scombrid fisheries. Central Marine Fisheries Research Institute, Kochi, pp 56-61

Prabhakar A, Dudley RG (1989) Age, growth and mortality rates of longtail tuna Thunnus tonggol (Bleeker) in Omani waters based on length data. Indo-Pac Tuna Dev Manag Progr 16:90-96

Ricker WE (1975) Computation and interpretation of biological statistics of fish populations. Bulletin of the Fisheries Research Board of Canada. The Blackburn Press, New Jersey

Sokal RR, Rohlf FJ (1987) Introduction to biostatistics, 2nd edn. Freeman Publication, New York

Sparre P, Venema SC (1998) Introduction to tropical fish stock assessment. FAO Fisheries Technical Paper, Rome

Stequert B, Panfili J, Dean JM (1996) Age and growth of yellowfin tuna, Thunnus albacares, from the western Indian Ocean, based on otolith micro-structure. Fish B-NOAA 94:124-134

Su NJ, Sun CL, Ye SR (2003) Estimation of growth parameters and age composition for yellowfin tuna, Thunnus albacares, in the Western Pacific using the length-based MULTIFAN method. J Fish Soc Taiwan 30:171-184

Supongpan S, Saikliang P (1987) Fisheries status of tuna purse seiners (using sonar) in the Gulf of Thailand. Department of Fisheries, Bangkok

Taghavi Motlagh SA, Hashemi SA, Kochanian P (2010) Population biology and assessment of Kawakawa (Euthynnus affinis) in coastal waters of the Persian Gulf and Sea of Oman (Hormozgan Province). Iran J Fish Sci 9:315-326

Valset A, Bouchon-Navaro Y, Louis M, Bouchon C (2007) Weight-length relationships for 20 fish species collected in the mangroves of Guadeloupe (Lesser Antilles). J Appl Ichthyol 24(1):99-100

Wang Y, Ellis N (2005) Maximum likelihood estimation of mortality and growth with individual variability from multiple lengthfrequency data. Fish B-NOAA 103:380-391

Wootton RJ (1998) Ecology of teleost fishes. Kluwer Academic Publishers, Dordrecht

Yesaki M (1989) Estimates of age and growth of kawakawa (Euthynnus affinis), longtail tuna (Thunnus tonggol) and frigate tuna (Auxis thazard) from the Gulf of Thailand based on length data. Indo-Pac Tuna Dev Manag Progr 17:94-108 
Yoon HS, An YK, Hwang JH, Lim HS, Lee WK, Han KH, Lee SH, Choi SD (2013) Length-weight relationships for 14 fish species of the Suer River estuary in southern Korea. J Appl Ichthyol 29:468-469

Zhu G, Xu L, Dai X, Liu W (2011) Growth and mortality rates of yellowfin tuna, Thunnus albacares (Perciformes: Scombridae), in the eastern and central Pacific Ocean. J Zool 28(2):199-206 